\title{
Improving the quality of tiger shrimp Penaeus monodon through dietary incorporation of algae as a source of natural pigment
}

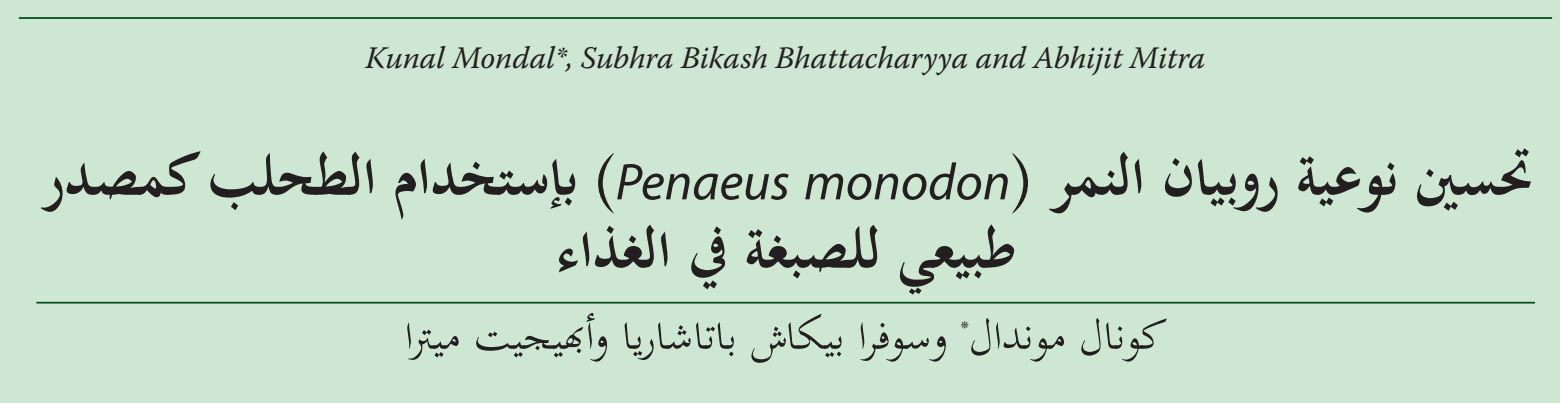

Abstract. Tiger shrimp is one of the major candidate species for export oriented aquaculture which dominates the seafood market in regions of European Union, Japan and USA. Carotenoid content in seafood has now become one of the important criteria in determining the quality of edible product. Recent trends in supplementing fish diets with natural pigment source are an alternative to the utilization of expensive synthetic pigments. In this context, green algae Enteromorpha intestinalis was selected as a source of natural pigment for inclusion in the diet of tiger shrimp Penaeus monodon. Astaxanthin being an important category of carotenoid pigment was monitored in shrimp muscle tissue during the feeding trial. Significant variation $(\mathrm{p}<0.05)$ was observed between the experimental groups as confirmed through ANOVA thus exhibiting higher astaxanthin content of shrimps $\quad(18.70 \pm 4.48 \mathrm{ppm})$ fed with E. intestinalis incorporated diet as compared to control $(15.80 \pm 2.33 \mathrm{ppm})$. The present programme therefore emphasizes on the quality improvement of aquaculture product by dietary inclusion of algae as a natural pigment source.

Keywords: Shrimp; aquaculture, feed, algae, pigment.

$$
\begin{aligned}
& \text { المستخلص: يعتبر روبيان النمر أحد أهم الأنواع المستزرعة للتصدير التي تهيمن على سوق المأكولات البحرية في مناطق الاتحاد الأوروبي واليابان }
\end{aligned}
$$

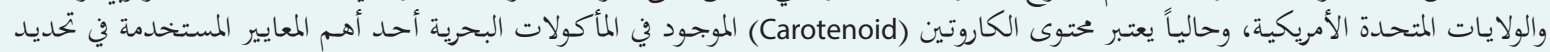

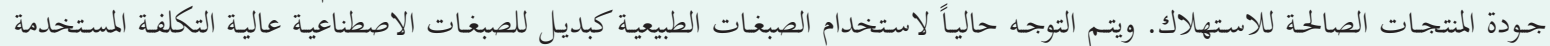

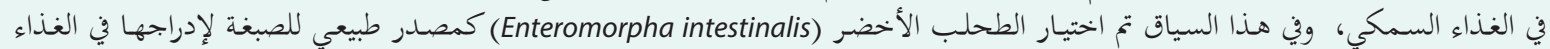

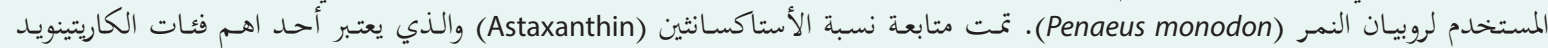

$$
\begin{aligned}
& \text { (Carotenoid) }
\end{aligned}
$$

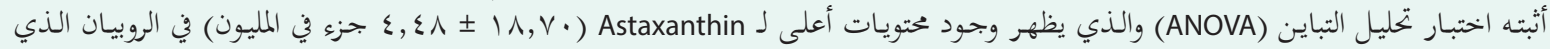

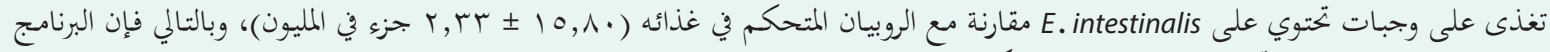

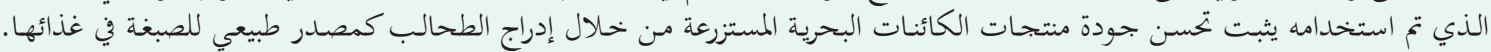

$$
\begin{aligned}
& \text { الكلمات المفتاحية: الربيان، الاستزراع السمكي، أعلاف الأحياء المائية، الطحالب، الصبغة }
\end{aligned}
$$

\section{Introduction}

I nclusion of algae as dietary supplement in animals have been investigated previously as a source of pigment (Strand et al., 1998). The effects of dietary inclusion of algae have resulted in improved performance including better animal product quality (Moss, 1994; Penaflorida and Golez, 1996; Cruz-Suarez et al., 2000). To be more specific the commercial production of shrimps and prawns as an edible food product represents one of the fastest growing areas of aquaculture

* Department of Marine Science, University of Calcutta, 35 B.C. Road, Kolkata - 700019, India . Kunal Mondal ( $\longrightarrow$ ) email: bottu.marine@ gmail.com.
(Rosenberry, 2005) with high consumer appeal and attractive market for shrimps due to their body colouration or pigmentation which is a direct measure of its astaxanthin content. Carotenoid utilization by aquaculture species is well documented as it plays a regulatory role in providing antioxidant and pro-vitamin A activity, enhancing immune response, improving reproductive performance, growth, maturation and photo-protection (Howell and Matthews, 1991). They also help the species to resist environmental stress (Meyers, 1994). Algae and higher groups of plants are the major producers of carotenoids which comprises a family of over 600 natural fat soluble pigments (Britton et al., 1981). Studies reveal that alternative utilization of plant pigments in formulated diets have improved the body pigmentation 


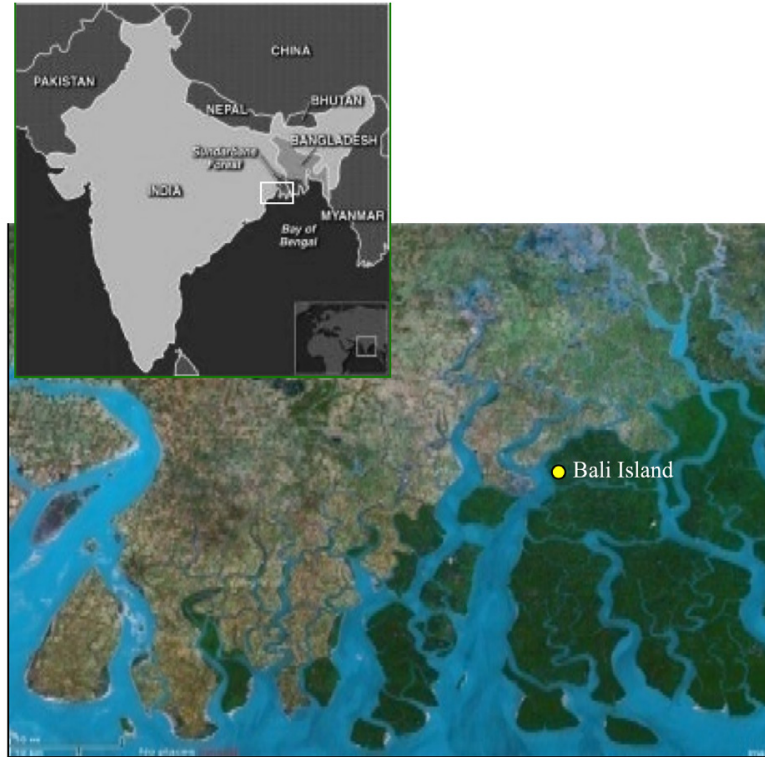

Figure 1. Map showing the $P$. monodon farming site at Bali Island of Indian Sundarbans.

of farmed crustaceans, particularly penaeids in order to achieve better market price (Lorenz, 1998; Liao and Chien, 1994).

Therefore the present work is an attempt to utilize Enteromorpha intestinalis as a natural dietary pigment source for farmed tiger shrimp (Penaeus monodon) in relation to its quality improvement.

\section{Materials and methods}

\section{Collection of algae and preparation of experi- mental diets}

Live and healthy algae Enteromorpha intestinalis was collected from Bali Island (22 04' 35.17" N latitude and $88^{\circ} 44^{\prime} 55.70^{\prime \prime}$ E longitude) of Indian Sundarbans during low tide. The collected material was rinsed in ambient water and then with distilled water, oven-dried at $50^{\circ} \mathrm{C}$ and finally processed to make powder. Experimental diet was formulated through incorporation of algae $\left(\right.$ Diet $\left._{\mathrm{ENT}}\right)$ at a level of $5 \%$. Simultaneously a control diet $\left(\right.$ Diet $_{C}$ ) was also formulated to study the comparative performance (Table 1).

\section{Feeding trial}

A feeding trial was run at Bali Island $\left(22^{\circ} 04^{\prime} 35.17^{\prime \prime} \mathrm{N}\right.$ latitude and $88^{\circ} 44^{\prime} 55.70^{\prime \prime}$ E longitude) of Sundarbans in grow-out ponds for 90 days of experimental duration (Fig. 1). Shrimp juveniles were procured from hatchery and stocked in experimental ponds at a density of 2 individuals $/ \mathrm{m}^{2}$. Experimental diets were randomly assigned, the culture species were fed twice daily and the uneaten feed was checked at regular intervals.
Table 1. Formulation of experimental diets.

\begin{tabular}{lll} 
Ingredients & Diet Control & Diet $_{\text {Enteromorpha }}$ \\
Fish meal & 35 & 30 \\
Soybean oil cake & 11 & 11 \\
Mustard oil cake & 11 & 11 \\
Rice polish & 23 & 23 \\
Wheat flour & 16 & 16 \\
$\begin{array}{l}\text { oyster shell dust } \\
\text { Shark oil }\end{array}$ & 2 & 2 \\
$\begin{array}{l}\text { Enteromorpha } \\
\text { intestinalis (source } \\
\text { of astaxanthin) }\end{array}$ & 0 & 2 \\
\hline
\end{tabular}

\section{Astaxanthin analysis}

The astaxanthin content in shrimp muscle tissue was analyzed according to the spectrophotometric method outlined by Schuep and Schierle (1995). Its value in \% was converted to ppm level for easy interpretation of data. The body colouration of shrimps after boiling was compared by Roche SalmoFanTM colour score.

\section{Statistical analysis}

The collected data were finally subjected to one-way analysis of variance (ANOVA). All statistical calculations were performed with SPSS 9.0 for Windows.

\section{Results and discussion}

The average astaxanthin content in muscle tissue was higher in shrimps fed with DietENT as compared to DietC (Table 2). A darker orange-red colouration was observed in shrimps fed with DietENT after boiling them in water for 5 minutes when compared with Roche SalmoFanTM colour score. The colour score was 30 for DietENT fed shrimps whereas a score of 27 was recorded from shrimps fed with DietC. ANOVA results showed significant variation $(\mathrm{p}<0.05)$ in average astaxanthin content which may be attributed to the capability of P. monodon to easily convert the fraction of algal astaxanthin into tissue astaxanthin. The Enteromorpha

Table 2. Variations in astaxanthin content of $P$. monodon (ppm muscle tissue) fed with experimental diets.

\begin{tabular}{|c|c|c|}
\hline $\begin{array}{l}\text { Days of culture } \\
\text { (DOC) }\end{array}$ & Diet Control & Diet Enteromorpha \\
\hline 0 & $12.83 \pm 0.22$ & $13.02 \pm 0.27$ \\
\hline 30 & $15.21 \pm 0.22$ & $17.62 \pm 0.55$ \\
\hline 60 & $16.96 \pm 0.53$ & $20.71 \pm 0.76$ \\
\hline 90 & $18.22 \pm 1.23$ & $23.47 \pm 1.31$ \\
\hline Average & $15.80 \pm 2.33 b$ & $18.70 \pm 4.48 \mathrm{a}$ \\
\hline
\end{tabular}

*Means with different letters $(a, b)$ in a row differ significantly $(p<0.05)$; values are means of three replicates 
sample selected for the investigation is found to contain $120.78 \mathrm{ppm}$ astaxanthin as reported from the present study region (Mitra et al., 2013; Banerjee et al., 2009; Chakraborty and Santra, 2008). Carotenoid, particularly astaxanthin content of feed is one of the major factors influencing the colour development in animals (Moretti et al., 2006) but at the same time scientific knowledge about several factors like dietary pigment source, their dosage level, feeding duration, dietary composition and magnitude of carotenoid esterification is also required to identify these interaction processes (Meyers and Latscha, 1997; Bjerkeng, 2000; Buttle et al., 2001; Gomes et al., 2002; White et al., 2002).

The present study showed significantly different astaxanthin content of the farmed shrimp which are in agreement to the observations that crustaceans exhibit strong tendency towards selection of specific carotenoids at a specific rate for their metabolic absorption (Meyers and Latscha, 1997). Similar work conducted from the present study region reveal that $P$. monodon when fed with diet containing red algae Catenella repens at a level of $5 \%$ improved the body astaxanthin content (Banerjee et al., 2010). The search for natural astaxanthin was not only limited to the algal resources, rather salt-marsh grass Porteresia coarctata was also tested as a natural dietary astaxanthin source in $P$. monodon feed with better results from the present geographical locale (Mitra et al., 2011, 2013). In continuation such natural carotenoid supply to the diet of shrimps has been studied for P. japonicus and Litopenaeus vannamei too from different parts of the globe. The ingredients of natural origin that have been used in the diet are red yeast (Phaffia rhodozyma) and microalgae Dunaliella salina (Chien and Jeng, 1992); Chnoospora minima (Menasveta et al., 1993); Spirulina sp. (Liao et al., 1993; Chien and Shiau, 1998); Haematococcus pluvialis (Chien and Shiau, 1998) and Isochrysis galbana (Pan et al., 2001). An usual trend of marked increase in the body carotenoid content has been observed when organisms were fed with plant pigment source diets. For example, feed supplemented with $50 \mathrm{ppm}$ algal material (Dunaliella salina) improved the body colouration of $P$. monodon (Boonyaratpalin et al., 2001). Three types of diet when provided to $P$. semisulcatus containing natural carotenoid sources like red pepper and marigold flower resulted in higher carotenoid accumulation in body tissues (Gocer et al., 2006). However research findings from Mexico also reported that feed incorporated with cultivated green alga Ulva clathrata significantly improved the body pigmentation of farmed shrimp L. vannamei (Cruz-Suarez et al., 2009).

\section{Conclusions}

Improved product quality of farmed $P$. monodon clearly reflects the transforming potential of algal astaxanthin into the body tissues by the particular culture species. Thus the present study provides a baseline in- formation about the natural astaxanthin pool of the Indian Sundarbans which may serve as an alternative to synthetic astaxanthin in animal diets which are more expensive.

\section{References}

Banerjee, K., R. Ghosh, S. Homechaudhury, and A. Mitra. 2009. Biochemical composition of marine macroalgae from Gangetic Delta at the Apex of Bay of Bengal. African Journal of Basic and Applied Science 1(56): 96-104.

Banerjee, K., A. Mitra, and K. Mondal. 2010. Cost-effective and eco-friendly shrimp feed from red seaweed Catenella repens (Gigartinales: Rhodophyta). Current Biotica 8(1): 23-43.

Bjerkeng, B. 2000. Carotenoid pigmentation of salmonid fishes - recent progress. In: Avances en Nutrición Acuícola V - Memorias del Quinto Simposium Internacional de Nutrición Acuícola, Mérida, México, 19-22 Noviembre 2000, L.E. Cruz-Suárez, D. Ricque-Marie, M. Tapia-Salazar, M.A. Olvera-Novoa and R. Cerecedo-Olvera (editors), 71-89. Universidad Autónoma de Nuevo León, Monterrey, Mexico.

Britton, G., G.M.S. Armitt, Y.M.A. Lau, K. Patel, and C.C. Shone. 1981. Carotenoproteins. In: Carotenoid Chemistry and Biochemistry, G. Britton and T.W. Goodwin (editors), 237-251. Pergamon press, Oxford.

Buttle, L.G., V.O. Crampton, and P.D. Williams. 2001. The effect of feed pigment type on flesh pigment deposition and colour in farmed Atlantic salmon, Salmo salar L. Aquaculture Research 32: 103-111.

Boonyaratpalin, M., S. Thongrod, K. Supamattaya, G. Britton, and L.E. Schlipalius. 2001. Effects of $\beta$-carotene source, Dunaliella salina, and astaxanthin on pigmentation, growth, survival and health of Penaeus monodon. Aquaculture Research 32(1): 182-190.

Chakraborty, S., and S.C. Santra. 2008. Biochemical composition of eight benthic algae collected from Sunderban. Indian Journal of Marine Sciences 37(3): 329-332.

Chien, Y.H., and S. Jeng. 1992. Pigmentation of kuruma prawn Penaeus japonicus Bate, by various pigment sources and levels and feeding regimes. Aquaculture 102: 333-346.

Chien, Y.H., and W.C. Shiau. 1998. The effects of Haematococcus pluvialis, Spirulina pacifica and synthetic astaxanthin on the pigmentation, survival, growth and oxygen consumption of kuruma prawn, Penaeus japonicus Bate. In: Book of Abstracts of World Aquaculture '98 Baton Rouge, Anonymus (editor), pp. 156. World Aquaculture Society, LA, USA.

Cruz-Suarez, L.E., D. Ricque-Marie, M. Tapia-Salazar, and C. Guajardo-Barbosa. 2000. Uso de harina de kelp 
(Macrocystis pyrifera) en alimentos para camaro' n. In: Avances en Nutrición Acuícola V - Memorias del Quinto Simposium Internacional de Nutrición Acuícola, Mérida, México, 19-22 Noviembre 2000, L.E. Cruz-Suárez, D. Ricque-Marie, M. Tapia-Salazar, M.A. Olvera-Novoa and R. Cerecedo-Olvera (editors), 227-266. Universidad Autónoma de Nuevo León, Monterrey, Mexico.

Cruz-Suarez, L.E., M. Tapia-Salazar, M.G. Nieto-Lopez, C. Guajardo-Barbosa, and D. Ricque-Marie. 2009. Comparison of Ulva clathrata and the kelps Macrocystis pyrifera and Ascophyllum nodosum as ingredients in shrimp feed. Aquaculture Nutrition 15: 421430.

Gocer, M., M. Yanar, M. Kumlu, and Y. Yanar. 2006. The effects of red pepper, marigold flower and synthetic astaxanthin on pigmentation, growth and proximate composition of Penaeus semisulcatus. Turkish Journal of Veterinary and Animal Sciences 30: 359-365.

Gomes, E., J. Dias, P. Silva, L. Valente, J. Empis, L. Gouveia, J. Bowen, and A. Young. 2002. Utilization of natural and synthetic sources of carotenoids in the skin pigmentation of gilthead sea bream (Sparus aurata). Journal of European Food Research Technology 214: 287-293.

Howell, B.K., and A.D. Matthews. 1991. The carotenoids of wild and blue disease affected farmed tiger shrimp (Penaeus monodon, Fabricus). Comparative Biochemistry and Physiology 98: 375-379.

Liao, W.L., S.A. Nur-E-Bohran, S. Okada, T. Matsui, and K. Yamaguchi. 1993. Pigmentation of cultured black tiger prawn by feeding with a Spirulina supplemented diet. Nippon Suisan Gakkaishi 59(1): 165-169.

Liao, I.C., and Y.H. Chien. 1994. Culture of kuruma prawn Penaeus japonicus in Asia. World Aquaculture 25: 18-33.

Lorenz, T. 1998. A review of the carotenoid astaxanthin as a pigment source and vitamin for cultured Penaeus prawn. NatuRosea Technical Bulletin 51: 1-7.

Menasveta, P., W. Worawattanamateekul, T. Latscha, and J.S. Clark. 1993. Correction of black tiger prawn (Penaeus monodon Fabricus) colouration by astaxanthin. Aquaculture Engineering 12: 203-213.

Meyers, S.P. 1994. Developments in world aquaculture, feed formulations and role of carotenoids. Pure and Applied Chemistry 66(5): 1069-1076.

Mitra A., R. Ghosh, A. Mallik, K. Mondal, S. Zaman, and K. Banerjee. 2013. Study on the role of mangrove based astaxanthin in shrimp nutrition. In: Sensitivity of Mangrove Ecosystem to Changing Climate, A. Mitra (Editor), 297-310. Springer Publishers, India.

Mitra A., K. Mondal, and K. Banerjee. 2011. Effect of salt-marsh grass (Porteresia coarctata) diet on growth performance of black tiger shrimp, Penae- us monodon. In: Diversification of Aquaculture, A. Sinha, S. Datta and B.K. Mahapatra (editors), 219232. Narendra Publishing House, New Delhi.

Moss, S.M. 1994. Growth rates, nucleic acid concentrations and RNA/DNA ratios of juvenile white shrimp, Penaeus vannamei Boone, fed different algal diets. Journal of Experimental Marine Biology and Ecology 182: 193-204.

Moretti, V.M., T. Mentasti, F. Bellagamba, U. Luzzana, F. Caprino, G.M. Turchini, I. Giani, and F. Valfre. 2006. Determination of astaxanthin stereoisomers and colour attributes in flesh of rainbow trout (Oncorhynchus mykiss) as a tool to distinguish the dietary pigmentation source. Journal of Food Additives and Contaminants 23: 1056-1063.

Meyers, S.P., and T. Latscha. 1997. Carotenoids. In: Crustacean Nutrition, L.R.D. DA' bramo, D.E. Conclin and D.M. Akiyama (editors), 164-193. Advances in World Aquaculture, The World Aquaculture Society, Baton Rouge, LA, USA.

Pan, C.H., Y.H. Chen, and J.H. Chen. 2001. Effects of light regime, algae in water and dietary astaxanthin on pigmentation, growth and survival of black tiger prawn Penaeus monodon post-larvae. Zoological Studies 40(4): 371-382.

Penaflorida, V.D., and N.V. Golez. 1996. Use of seaweed meals from Kappaphycus alvarezii and Gracilaria heteroclada as binders in diets of juvenile shrimp Penaeus monodon. Aquaculture 143: 393-401.

Rosenberry, B. 2005. World shrimp farming 2005. Shrimp News International 276pp.

Schuep, W., and J. Schierle. 1995. Astaxanthin determination of stabilized, added astaxanthin in fish feeds and pre-mixes. In: Carotenoids Isolation and Analysis, 273-276. Birkhauser Verlag Basel.

Strand, A., O. Herstad, and S. Liaaen-Jensen. 1998. Fucoxanthin metabolites in egg yolks of laying hens. Comparative Biochemistry and Physiology 119: 963974.

White, D.A., G.I. Page, J. Swaile, A.J. Moody, and S.J. Davies. 2002. Effect of esterification on the absorption of astaxanthin in rainbow trout, Oncorhynchus mykiss (Walbaum). Aquaculture Research 33: 343-350. 